\begin{tabular}{ccc}
\hline International Journal of Engineering \& Technology, $7(3.7)(2018) 283-286$ \\
SPC & Website: $w$ ww. sciencepubco.com/index.php/IJET \\
Research paper & Technology \\
\hline
\end{tabular}

\title{
E-office Users Experience, Drivers and Obstacles
}

\author{
Endang Fitriyah Mannan ${ }^{1}$, Dyah Puspitasari Srirahayu, Nove Eka Variant Anna, Dessy Harisanty \\ ${ }^{1}$ Library Studies, Department of Engineering, Vocational Faculty, Universitas Airlangga, Surabaya, Indonesia \\ *Corresponding author: *Endang Fitriyah Mannan: Library Studies, Department of Engineering, Vocational Faculty, \\ Universitas Airlangga, Surabaya, Indonesia \\ E-mail: endang_fitriyah@yahoo.com
}

\begin{abstract}
Document management in an organization is very important because it is not only to facilitate the documents retrieval, but also to enhance the competitive power of the organization. For this purpose, Faculty of Vocational Studies Airlangga University applies electronic document management, called e-office. The e-office system is implemented to manage the existing administration system at Airlangga University, where users can create letters, make deliveries, receive letters, reply letters and make memos. This study aims to determine eoffice utilization in the environment of the Faculty of Vocational Studies Airlangga University. Research method used is a descriptive quantitative approach. The target population in this research is Vocational Faculty Employee who has e-office account. The sampling technique used is a census technique or a full sample. The results show that not all e-office account owners have a habit of accessing eoffice every day. The most done activity when accessing e-office are reading and printing mail. E-office users believe that using this system can be a solution to the problem of limited storage space and says it is easier to control than before e-office exist. The most accessed information using e-office is student information and the obstacle faced is lack of training for e-office users.
\end{abstract}

Keywords: Electronic Document Management Systems, e-office, System utilization

\section{Introduction}

Many organizations have problems in document management. They feel immersed in documents they have created. Documents are created along with the activities of the organization. The larger the organization, the more documents it generates, and the more complex it is to manage. With the large number of documents, they can result in difficulty retrieving information. Difficulty in retrieving documents will hinder the development process of an organization, thereby reducing the organization's competitive power. Similarly, this is also experienced by the Faculty of Vocational Studies, where the faculty that was established since 2014 has begun to get many problems related to the retrieval of documents, from missing documents, tucked, unclear document flow, and et cetera.

The results suggest that $90 \%$ of corporate memory is stored in documents, $90 \%$ of the resulting documents are mixed up with each other, and the organization spends a lot of money on filing the documents and spend more money to find the lost document, and more money is spent to produce missing documents. $7.5 \%$ of organizational documents are lost and $3 \%$ of documents are incorrectly placed at the time of storage folder, and the average employee spends 30 minutes to 2 hours to find the document, reported by Coopers \& Lybrand [1]. This result has been done long time ago, but still be able to represent the condition of organization and documents in the digital era. Organizations are also still experiencing issues related to the retention and documents retrieval.

Considering the importance of documents and the amount of funds spent if documents are not properly managed, organizations are now beginning to care about the management of their documents, and many organizations are investing their funds to purchase a document management systems package for their documents management. Document management companies are also emerging, like Fujitsu's service providers who expand the network to manage digital documents [2]. In addition to utilizing the services of professional document managers, organizations can also build their own document management system, with condition they already have adequate human resources.

To overcome this problem, many organizations are making innovations in the document management system by utilizing information technology with the application of electronic document management. According to Green, William B[3] electronic document management system (EDMS) is a process of processing documents stored in digital format by utilizing scanning equipment and can be diverted, displayed, stored and retrieved by utilizing existing information technologies such as computers.

Electronic Document Management system (EDMS) in Airlangga University is known as e-office system. E-office is a term created to cover the increasing use of information technology-based computers for office work, especially in the 1980s, reported by Sigit Dawandaru [7]. Over the times and with the policy of bureaucratic in Indonesia which requires every business process or the activities of local government offices must proceed efficiently and effectively resulting into the transformation of business processes from conventional or manual systems to automation systems. Manually processed business processes (document driven) describe the sending of a document, such as a letter that is still hardcopy, and sent by courier in the office environment.

The e-office system is implemented to manage the existing administration system at Airlangga University, where users can create letters, make deliveries, receive letters, reply to letters and make memos using the e-office system. Through this e-office system users are also able to browse to where the mail users send 
and can find out whether the mail sent has been processed or not, so users do not have to worry about the mail sent. The process of retrieving documents is also facilitated by the use of this e-office system and it is able to accelerate the flow of mailing and receiving letters that previously took a long time.

Implementation of e-office is still quite new, in the year 2013 which was originally used for purposes in the university management office. Furthermore, in 2014 e-office began to be introduced to all faculties, including the Faculty of Vocational Studies. E-office is still in use today. This paper aims to find out the e-office user experience as long as they take advantage of eoffice from 2015-2016. Then, it will be known the obstacles and impetus in the utilization of e-office. The results of this research can be utilized by faculty management to increase the e-office service.

Document Management Systems (DMS) refers to systems designed for document management activities. Documents here include electronic and manual documents. However, DMS generally refers to the management of electronic documents, reported by Adam [5].

The components of Document Management Systems are document repository, where the storage system is often stored on the hard disk of the network server. This storage must be a central storage for all organizational documents. Integration with desktop application, an EDMS must be integrated with computer applications used in the organization. For example, integrated with MS Office. Check in and check out are EDMS feature controls editor of the document and when the document is edited. First, Versioning is a mechanism by which the system can track changes that have been made to a document. It can be a version number, for example 1.1, 1.2, etc. The second is Auditing. This feature is related to version control, which is to check who have changed the document, and what changes have been made, and when changes occur. Here, more on to control the changes that occur on the document. The third is Security. It comes with access (permission) to view, edit and send documents. Fourth is Classification and indexing. This classification and indexing activity to facilitate retrieval of documents. Last, Search and retrieval. Once the document is classified and indexed, then the document is ready to be stored in the repository. The system that runs well is a system that has the mechanism of storing and retrieval of appropriate information. E-office adopts the features contained in the EDMS
Prior research suggests that the biggest obstacle in implementing document management systems is the need for substantial funds, time and energy to succeed. In addition, other obstacles arise are employees who do not want to learn with new methods and systems, and the use of systems that are not user friendly, reported by Ahmad et.al [6].

\section{Method}

This research uses descriptive quantitative approach. Descriptive analysis is used to describe the results of research in the form of data in the field that existed descriptively. The description is obtained by interpreting the results of data tabulation to support the results of the research analysis. Quantitative descriptive approach in this research is used to describe e-office utilization.

The location of this study was chosen at the Faculty of Vocational Studies Airlangga University with the consideration it is a newly established faculty and has been applied e-office system.

The target population in this research is the faculty employee who has e-office account. The sampling technique used is a census technique or a full sample. The reason for using this technique is because the population is less than 100 .

Data collection techniques conducted in this study are: a) primary data collection, which is collected by the author directly through a structured interview to the respondents by referring to the questionnaire. In addition to the questionnaires, data collection in this study was also conducted by probing method used to find out more about the unique (considered) trends expressed by the respondents; b) secondary data collection, which is obtained in a form that has been processed by certain parties, such as data from related institutions. After data is collected, the next step is data processing.

All collected primary data will be processed using SPSS for descriptive statistics, especially for the purpose of displaying a single frequency table. The quantitative data that have been processed is then analyzed and interpreted theoretically. Qualitative data obtained through the probing results of the respondents is also used to sharpen and enrich the analysis. Ultimately, this descriptive study seeks to provide a systematic overview of the facts and characteristics of the research unit.

\section{Findings}

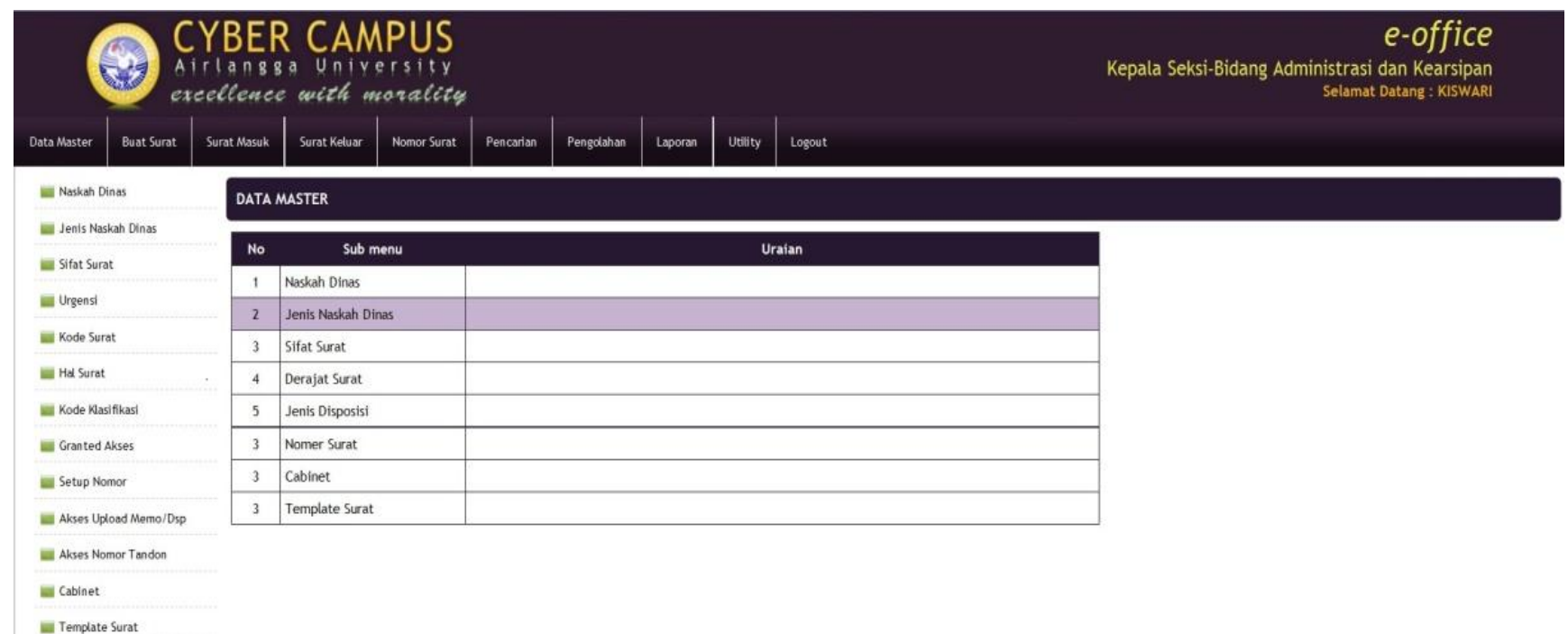


In this e-office system there are 10 main menus as seen in the above view of the master data, create a letter, incoming mail, outgoing mail, letter number, search, processing, reports, utility, and $\log$ out. The master data menu is used to add or modify existing modules. Mail menu is used to create letters but this menu is still disabled because there is no clear procedurs related to electronic mail creation. Incoming mail menu is used to view incoming mail to the user. Outgoing mail menu is used to be able to know the outgoing mailing process and monitor the outgoing mail, the mail- ing number menu is used to find out the letter number, script type, subject, officer, date, and also links related to the letter or document in the details column. The utility menu is used for user management, sending SMS, user sync, unread mail, re- upload, and agenda monitoring. From the various menus, not all of the menu used by e-office users at Faculty of Vocational Studies Airlangga University. Below is the data.

Table 1. Activities While Opening E-Office

\begin{tabular}{|c|c|c|c|c|c|c|c|}
\hline \multirow[t]{2}{*}{ No } & \multirow[t]{2}{*}{ Kinds of Activity Being Done } & \multicolumn{2}{|c|}{ Yes } & \multicolumn{2}{|l|}{ No } & \multicolumn{2}{|c|}{ Total } \\
\hline & & $\mathrm{F}$ & $\%$ & $\mathrm{~F}$ & $\%$ & $\mathrm{~F}$ & $\%$ \\
\hline 1. & Reading letters & 32 & 62.7 & 19 & 37.3 & 51 & 100 \\
\hline 2. & Printing letters & 44 & 86.3 & 7 & 13.7 & 51 & 100 \\
\hline 4. & Sending letters & 12 & 23.5 & 39 & 76.5 & 51 & 100 \\
\hline 5. & Taking numbers & 10 & 19.6 & 41 & 80.4 & 51 & 100 \\
\hline 6 & Making letters & 14 & 27.5 & 37 & 72.5 & 51 & 100 \\
\hline 7 & Dissociating letters & 6 & 11.8 & 45 & 88.2 & 51 & 100 \\
\hline 8 & Others & 7 & 13.7 & 44 & 86.3 & 51 & 100 \\
\hline
\end{tabular}

Daily e-office access done by employees at the Vocational Faculty, most of the employees still have not accessed e-office already provided, as many as 30 employees or 58.8 admitted that they do not access e-office, while as many as 21 employees or $41.2 \%$ who access e -office every day. Most respondents are not familiar with the existence of e-office $(52.9 \%)$. Although the information is already provided in the e-office, employees still need a printed form. Therefore, nowadays the dissemination of information other than e-office, the information is also disseminated either through social media (WhatsApp) or in printed form, even the advantages of access to information in e-office is quite fast and accurate. For urgent information, the recipient of the message an SMS will be sent to them to remind to open immediately. Average allocation of time employed by employees to access e-office more than 2 hours. Some users do not perform the existing activities in e-office. This is because in the e-office system at Airlangga University consisting of five levels associated with the duties and responsibilities of each letter administrator, management, operators, and registrations and users administrator. The letter administrator level is responsible for managing the e-office system. Management level can access the information contained in the e-office system thoroughly with the note that the information is located under the work unit under it. The operator level can access the received letter only without being able to see mail received by others. Registration level is responsible for creating mailing numbers. The administrator level of the user is assigned to deliver the mail and cannot access the mail unless it gets permission from the management, so in the table above there are $66.7 \%$ of users who provide the letter information in the e-office to the leadership. Other users can view the contents of other users' information if they are given certain permissions to view the mail from the leader and they termed this as 'granted'.

Table 1 shows the activities undertaken by the Vocational Faculty's employees when they are opening the e-office. The majority of employees do e-office printing activities, as much as $86.3 \%$ and employees who do the activity of reading mail in the e-office as much as $62.7 \%$. Both activities are in accordance with most employees responsibilities. Reports to the leaders done as much as $33.3 \%$. This is because of the above reasons that many leaders of KPS and dean missed for opening e-office so that administrators of department or secretary are advised to inform their boss if there is information in e-office. The facility of taking a number should only be done by the secretarial and recording sections in order to be easy to control. Disposing the letter activity are done by very few employees (11.8\%). This is because only dean can dispose the letter.
According to Adam [5], one of the basic components in electronic document management system (EDMS) is as a document repository that serves to store all documents that have been generated by an agency so that users can perform documents retrieval by search and retrieval or browsing functionality. The e-office system of Airlangga University also has the function and one of them is for the document storage to be easily rediscovered and reduce the number of piles of paper on the table or workspace as happened in the communications and informatics office of East Java province, the employee also be easier to feel the comfort with the reduction of piles of paper work After using e-office [7].

One of the things to be achieved in the use of e-office is the reduction of paper in office activities. The term Paperless Office was first created in 1975, the idea being that office automation would make paper use superfluous for routine tasks such as records and bookkeeping, and that would change with the introduction of personal computers [8]. The implementation of paperless office is widely understood as an effort to replace documents in paper form that exist in traditional offices with documents in electronic format such as doc, pdf, and so on, reported by Mayer ${ }^{8}$. Paperless office systems replace manual search process documents by search process in electronic document collection. Such systems have not maximized the potential offered by information and communication technologies such as remote collaboration and so on, reported by Ashdown [9]. However, in its implementation it cannot run maximally like in Faculty of Vocational Studies although already using e-office for correspondence administration but there are still $29.4 \%$ who always print the document to be submitted to the leaders and there are $58.8 \%$ of users who rarely print the documents.

Acceptance of a new system by the user will not be separated from ease of use offered by the system. Moore and Benbasat stated that ease of use is one of the factors that causes the person to continue using the system or stop [10]. From the results of data processing in the can that $93.1 \%$ of Airlangga University e-office users stated that e-office facilitate for storage and information management to support their work.

From the 51 e-office users of the Vocational Faculty, $54.9 \%$ of users agreed that e-office is one of the solution for limited storage space and $98 \%$ said it was easier to control than before e-office. Security is a very important component in electronic document in Electronic Document Management Systems (EDMS). The security applied to the system may grant different access permissions at each user level where this is applied in Airlangga University's eoffice by creating five user levels as mentioned above, repoerted by Adam Azad [5]. 
Table 2. Constraints When Accessing E-Office

\begin{tabular}{|l|l|l|l|l|l|l|l|}
\hline \multirow{2}{*}{ No } & Kinds of Constraints & Yes & No & \multicolumn{2}{l|}{ Total } \\
\cline { 3 - 8 } & & F & $\%$ & F & $\%$ & F & $\%$ \\
\hline 1. & Slow internet connection & 16 & 31.4 & 35 & 68.6 & 51 & 100 \\
\hline 2. & Lack of training & 43 & 84.3 & 8 & 15.7 & 51 & 100 \\
\hline 3. & Computers or gadgets are not supported & 15 & 29.4 & 36 & 70.6 & 51 & 100 \\
\hline 4. & Others & 4 & 7.8 & 47 & 92.2 & 51 & 100 \\
\hline
\end{tabular}

Although e-office can be accessed quickly, accurately, and can be out of the office but there are constraints of Vocational Faculty employees when accessing e-office. Most of them admitted that the lack of training became the greatest constraints, as much as $84.3 \%$. A total of $31.4 \%$ of the problem in slow internet network As many as $29.4 \%$ of the obstacles are unsupported media, and as many as 4 employees or $7.8 \%$ are hampered by other obstacles. Thus, it can be seen that the obstacles faced by employees when accessing e-office occurred both from within and from outside. This inner constraint is due to lack of understanding of employees in accessing e-office. Employees therefore need effective training. During this training has been done but still felt less by employees. Therefore, training methods can be tailored to the needs of employees. Training methods can be done either independently or in groups. In addition to internal constraints, visible constraints also come from external such as non-supported media or slow internet connection.

Table 3. Gadgets Used For Accessing E-Office

\begin{tabular}{|l|l|l|l|}
\hline No & Gadgets & F & $\%$ \\
\hline 1. & Computer & 28 & 54.9 \\
\hline 2. & Laptop & 9 & 17.6 \\
\hline 3. & Smartphone & 4 & 7.8 \\
\hline
\end{tabular}

Table 3 shows the types of gadgets used by Vocational Faculty employees to access e-office. The majority of employees use the computer, which is as many as 28 employees or $54.9 \%$. As many as 9 or $17.6 \%$ are using laptops. As many as 4 employees or $7.8 \%$ are using smartphones, and as many as 10 employees or $19.6 \%$ use other gadgets. Every employee is computer-facilitated for his work. Therefore, most of them are using computer to access eoffice.

\section{Conclusion}

From this research, it can be concluded that the utilization of eoffice in the environment Faculty of Vocational Studies is not yet maximally ran, even the system give much benefit in management of document in organization. To maximize the utilization of eoffice, the faculty need to continuously socialize and train the eoffice account owner so that accessing this system will become a habit. The access facilities also need to be improved, especially for stable internet connection.

\section{References}

[1] L. Coopers \& L. L. P. Lybrand. Reinventug The University Mnaging and Financing Institutions of higher Education. New York: John Wiley Sons, Inc; 1998

[2] Fujitsu. Fujutsu Technology and Service Vision 2016. https://www.fujitsu.com/downloads/GLOBAL/vision/2017/downl oad-center/FTSV2017_Book2_EN_FV0046-2.pdf

[3] W. B. Green. Introduction to Electronic Document Management Systems. Toronto: Harcourt Brace Jovanovich. 1993.

[4] D. D. Sigit.Pemanfaatan Aplikasi E-Office Untuk mendukung Penerapan E-Government Dalam Kegiatan erkantoran Studi Kasus: Puslitbang Jalan Dan Jembatan. Seminar Nasional Teknologi Informasi dan Komunikasi 2013 (SENTIKA 2013). ISSN: 20899815, (2013).

[5] A. Adam. Implementing Electronic Document and Record Management Systems. New York : Auerbach Publications; 2008.

[6] H. Ahmad, I. M. Bazlamit, M. D. Ayoush. Investigation of Document Management Systems in Small Size Construction Companies in Jordan. Procedia Engineering 2017; 82: 3-9.
[7] A. A. Agustina. Pemanfaatan E-Office Dalam Korespondensi Sebagai Perwujudan Paperless Office Di Dinas Komunikasi Dan Informatika Provinsi Jawa Timur. Skripsi. Surabaya: Universitas Negeri Surabaya. 2013. available at www.jurnalmahasiswa.unesa.ac.id/index.php/jpap/article/view/125 $12+\& c d=5 \& h l=i d \& c t=c \operatorname{lnk} \& g l=i d$

[8] Business week. The Office of the Future. Business Week 1975; (2387): 48-70..

[9] M. Ashdown. Remote collaboration on desk-sized displays, Comp. Anim. Virtual Worlds 2013; 16: 41-51. DOI: 10.1002/cav.55

[10] G. C. Moore, I. Benbasat. Development of an instrument to measure the perceptions of adopting an information technology innovation. Inf Syst Res 1991; (3): 192-222. 